\title{
Analysis of Corporate Social Responsibility (CSR) Disclosure Toward Tax Aggressivity and Its Impacts on Investor Reaction
}

\author{
Nela Safelia Reni Yustien Widya Sari Wendri Afrizal ${ }^{*}$ \\ Faculty of Economics and Business of Jambi University, Jambi, Indonesia
}

\begin{abstract}
This study was administered to analyze and obtain empirical evidence regarding Corporate Social Responsibility (CSR) disclosure on tax aggressiveness and the impact of corporate CSR disclosure and tax aggressiveness on investor reactions. The population of this study were manufacturing companies listed on the Indonesia Stock Exchange (BEI) in 2016-2018. Samples were 147 companies selected using purposive sampling technique. Path analysis was performed to analyze the data of this study. The results of this study showed that CSR disclosure negatively affected the tax aggressiveness and CSR affected investor reactions. Further, tax aggressiveness did not affect investor reactions. In addition, CSR disclosure and tax aggressiveness did not share simultaneous influence on investor reactions.
\end{abstract}

Keywords: CSR Disclosure, tax aggressiveness, Investor Reaction, Profitability, Company Size and Leverage DOI: $10.7176 /$ RJFA/11-22-10

Publication date: November $30^{\text {th }} 2020$

\section{INTRODUCTION}

\subsection{Background}

Corporate social responsibility refers to companies' commitment in improving their business ethics by carrying out their operational activities legally, contributing for employees' quality of live and improving the economic condition of broader communities. CSR reflects companies' concerns on stakeholders (employees, customers, society and government) within their operational areas.

CSR is beyond voluntary activities as it is a form of companies' commitment in carrying out company operational activities, especially those that run their enterprises using natural resources. CSR is regulated in the "Law Number 40 of 2007. Article 74 concerning the Limited Liability Company Law".

Currently, concerns on environmental issues in relation to companies' operational activities are rising. This environmental awareness affects companies' profitability. When companies fail to care for the community and the environment, the community will not provide support for the company. Therefore, companies' images depend on the implementation of CSR.

The stakeholder theory states that corporate responsibility is not only attributed to owners (shareholders), but also to the social sphere of society (stakeholders). Thus, companies should have strong awareness on the environment to maintain the sustainability of their operational activities (Lanis \& Richardson 2015). Unfortunately, in fact, corporate social responsibility activities have been used by companies as tax aggressiveness practice. As mentioned in Law no. 36 of 2008 article 6 paragraph 1, "the amount of national tax revenue and business types are determined based on gross income minus operational costs to generate income" which include: donations that are parts of CSR costs.

Further, PP. 93 of 2010 mentions that, "Some company expenses related to Corporate Social Responsibility can be deductible expenses". This regulation does not rule out the company deliberately in spending high costs for CSR activities to reduce corporate taxes. Previous studies analyzing the effects of CSR on tax aggressiveness resulted in diverse findings as (Watson, 2011; Lanis \& Richardson 2011; Lin, KZ, Cheng, S., \& Zhang, F. 2017; Watson, L. 2015; Lanis \& Richardson 2015) who found negative correlation between CSR disclosure and tax aggressiveness. Meanwhile, Laguir et al. (2015) examined the relationship between CSR and tax aggressiveness and found positive effect.

CSR disclosure can affect investor reactions. Studies conducted by (Nuzula \& Kato 2012; Wenbin Sun, Shanji Yao 2018) proved that CSR affects investors' reactions as measured by abnormal return (AR). According to Jogianto (2015), "Abnormal return is an indicator that measures the current market situation". An information is perceived significant among investors if it triggers their reactions to make transactions in the capital market. Meanwhile, Lely and Silvia 2008 found that CSR disclosure had no effect on investors reactions. Findings on the disclosure of CSR towards investors reactions still varied.

Based on the aforementioned background, the authors were intrigued to analyze the influence of CSR disclosure on tax aggressiveness and its impact on investor reactions in manufacturing companies in Indonesia. Previous studies only analyzed the effect of CSR disclosure on tax aggressiveness, while in this study, the level of corporate CSR disclosure on tax aggressiveness was analyzed and its impact on investor reactions was also examined. 


\subsection{Research Questions}

1. How does Corporate Social Responsibility affect Tax Aggressiveness?

2. How does Corporate Social Responsibility affect Investor Reaction?

3. How does Tax Aggressiveness affect Investor Reaction?

\subsection{Objectives of the research}

This study was conducted to examine and obtain empirical evidences related to CSR disclosure on Tax Aggressiveness and to see how CSR disclosure and Tax Aggressiveness affect Investor Reaction.

\subsection{Benefit of the research.}

1. The results of this study can be used as an insights for investors in making investment decisions to companies.

2. This study also provides fruitful inputs regarding the importance of CSR disclose in sustainability reporting and to encourage companies to raise greater social awareness in making any decision.

3. This study also proposes recommendations for the government in creating laws and regulations for the quality improvement of environmental-based accounting standards.

\section{LITERATURE REVIEW}

\subsection{Corporate Social Responsibility}

Companies disclose their corporate social responsibility in sustainability reporting. Sustainability reporting is a report on economic policy, social environment that affects performance and products within the context of sustainable development. CSR shows companies' seriousness in maintaining business ethics to reduce negative impacts and increase companies' operational activities to all stakeholders in the economy and social environment to achieve sustainable development goals.

The revised PSAK No. 1 of 2009 explains that every company in Indonesia is given freedom to disclose their CSR information in annual reports. It is also stipulated in Law no. 40 of 2007 and supported by PP. 47 of 2012. At present, comprehensive CSR reports are written based on the Global Reporting Initiative's Sustainability Reporting Guidelines (GRI). GRI provide common ground that make CSR disclosure in the reports consistent. GRI provide guidelines that apply in global scope for the preparation of reports on companies' economic, environmental and social dimensions, products and services.

\subsection{Tax Aggressiveness}

Hlaing (2012) stated that tax aggressiveness is an effort of tax planning to reduce and make the amount of tax rate more effective. Whilst, (Chen et al 2014): "Between tax avoidance and tax evasion, there exist potential gray area of aggressiveness. This gray are exists because there are tax shelters beyond what is specifically allowed by the tax low and the tax law does not specifically address all possible tax transaction. A bright line does not exist between tax avoidance and tax evasion because neither term adequately describes all transaction. Therefore, aggressive transactions and decision-making may potentially become either tax avoidance or tax evasion issues". Lanis dan Richardson, 2015; Laguir et al, 2015; proxied Tax Aggressiveness and Effective Tax Rates (ETR).

\subsection{Investor Reaction}

Basically, investors appreciate the implementation of Corporate Social Responsibility, through which they could analyze the sustainability of a company. Investor reactions can be seen from the abnormal return (AT) value. Information that is useful for investors is if the one that triggers reactions to make transactions in the capital market. Investors' trust greatly influences the stock market reaction.

Jogiyanto (2015) defined "abnormal return as the gap between actual return and expected return". Abnormal return will be positive if the return obtained is greater than the expected return. Meanwhile, abnormal return will be negative if the return obtained is smaller than the expected return.

\subsection{Previous Studies}

In a previous study the authors conducted in 2018 and 2019 (Nela, S and Aulia, B (2018) it was found that "CSR had a significant negative effect on tax aggressiveness and profitability had no effect on tax aggressiveness". Nela, S and Widia, S (2019) found that "Profitability and company size had an effect on tax aggressiveness, while leverage did not".

A study done by Lanis, R., \& Richardson, 2012 stated that CSR disclosure has a significant negative effect on tax aggressiveness, social investment is the company's success strategy. In line with Lin, K. Z. Cheng, S, \& Zhang, F. 2017; Watson, L, 2015; empirical evidences showed that CSR had a negative effect on tax avoidance. Issam, Laguir, Raffaele Stagliano and Elbaz Jamal 2015, stated that CSR had a significant positive relationship to tax aggressiveness. Likewise, Khaoula (2013) found that the CSR was a significant variable that had a positive 
effect on tax aggressiveness (Richardson, Wang, \& Zhang, 2016

Wenbin Sun, Shanji Yao (2018) explained that CSR disclosure had a positive effect on encouraging company shareholder value, but the effect changed negatively when the company was excessively engaged in CSR activities. Nuzula and Kato, 2010 stated that corporate CSR disclosure in Japan obtained positive responses form investors. Furhter, Hanlon, M. and Slemrod, J. 2009 found that market reaction was highly dependent on how investors perceive the level of tax aggressiveness, while Frank, M., Lynch, L., Rego, S., 2009 showed that investors did not completely use accrual information and financial reports in making purchase decisions. Thus, investors do not react to tax aggressiveness.

The development of the model in this study includes what was not examined in prior studies regarding effect of CSR disclosure on tax aggressiveness. Other studies examined the influence of aggressiveness on corporate value, whereas in this study, the researchers put into account the level of corporate CSR disclosure on tax aggressiveness and examined the direct effect of CSR and aggressiveness on investor reactions. The roadmap of this study is presented in the following Figure.

\section{III.METHOD OF THE STUDY}

\subsection{Types and Sources of Data}

This study is a quantitative study, in which data were collected from companies. The hypotheses of this study were tested quantitatively based on numerical data analysis using statistical methods. The data of this study were secondary data obtained from companies Annual Reports and reports on stock trading transactions.

\subsection{Population and Samples}

The population of this study included manufacturing companies listed on the Indonesia Stock Exchange (IDX) in 2016-2018. Purposive sampling technique was performed to select companies based on several criteria; manufacturing companies listed on the Indonesia Stock Exchange for the period 2016-2018, manufacturing companies with incomplete data, companies that had taxable profit compensation. The sampling resulted in 49 samples times 3 years. Hence, 147 samples of manufacturing companies listed on the Indonesia Stock Exchange were involved in this study.

\subsection{Data Analysis Method}

The data obtained in this study were analyzed using Path Analysis. Path analysis is used to analyze the pattern of relationship among research variables. Path analysis also showed both direct and indirect influences of independent variables on dependent variables.

Remarks:

The path analysis equations used in this study are presented as follows.

$\mathrm{ETR}=\mathrm{P} 1 \mathrm{CSR}+\varepsilon_{1}$

$\mathrm{AR}=\mathrm{P} 1 \mathrm{CSR}+\mathrm{P} 2 \mathrm{ETR}+\varepsilon_{3}$

Hypotheses Testing

First Hypothesis

$\mathrm{H}_{0}: \mathrm{PYX} \leq 0$ : CSR Disclosure does not affect Tax Aggressiveness

$\mathrm{H}_{\mathrm{a}}: \mathrm{PYX}>0$ : CSR Disclosure positively affects Tax Aggressiveness

Second Hypothesis

$\mathrm{H}_{0}$ : P ZX $\leq 0$ : CSR Disclosure does not positively affect Investor Reaction

$\mathrm{H}_{\mathrm{a}}: \mathrm{P} Z \mathrm{ZX}>0$ : CSR Disclosure positively affects Investor Reaction.

Third Hypothesis

$\mathrm{H}_{0}: \mathrm{PZXY} \leq 0$ : Tax Aggressiveness does not positively affect Investor Reaction

$\mathrm{H}_{\mathrm{a}}: \mathrm{PZXY}>0$ : Tax Aggressiveness positively affects Investor Reaction

The influence of each variable was shown in the results of t-test. Prior to t-test, fit model test had been performed using F-test and Determination Coefficient.

\section{IV.RESULTS AND DISCUSSIONS \\ 4.1 Hypotheses Testing}

This section explains the statistical measurement used in performing the path analysis in this study.

The Influence of Corporate Social Responsibillity Disclosure on Tax Aggressiveness

The results of the t-test done to analyze wheter corporate social responsibility had any influence on tax aggressiveness are presented in Table 1. 
Table 1

The Results of Path Analysis on the First Sub-Structure

\begin{tabular}{|c|c|c|c|c|}
\hline Variable & Path Coefficient & R Square & t-score & Sig \\
\hline $\mathrm{X}$ & -0.191 & 0.038 & -2.236 & 0.027 \\
\hline
\end{tabular}

Source: processed secondary data, 2020

The path coefficient using structural equations to test the influence of corporate social responsibility disclosure (X) on Tax Aggressiveness is shown as follows.

$$
\mathrm{Y}=-0.191 \mathrm{X}+0.98 \varepsilon_{1} ; \quad R^{2}{ }_{Y X}=0.038
$$

The data processing resulted in a $t$-value for variable $X$ of -0.191 with a prob (sig) value $=0.027$ for $\alpha=0.05$. The prob (sig) value $(0.027>0.05)$ shows that $H_{0}$ is rejected and $H_{a}$ is accepted. The residual coefficient $P Y_{\varepsilon 1}=\sqrt{ }$ $(1-0.038)=0.96$. These results indicate that corporate social responsibility has a negative influence on tax aggressiveness. The R square that reflects the influence of CSR disclosure on tax aggressiveness is $3.8 \%$, indicating that corporate social responsibility disclosure affects the level of tax aggressiveness.

In this study, corporate social responsibility disclosure was found negatively related to tax aggressiveness. Corporate social responsibility disclosure will strengthen companies' images as they will be engaged in various social activities, activities to protect the environment, and they will show greater information transparency. Therefore, companies with adequate corporate social responsibility disclosure are less likely to do tax avoidance. Such positive images will increase shareholders' profits. The results of this study are consistent with prior studies done by (Weston 2015 and Lanis and Richardson, 2012).

The Influence of Corporate Social Responsibility Disclosure on Investor Reaction

The second structural model obtained in this study presenting the relationship among variable $\mathrm{X}, \mathrm{Y}$ and $\mathrm{Z}$ is presented in Table 2

Table 2

Results of Data Analysis of the Second Path Sub-Structure

\begin{tabular}{|l|l|l|l|l|l|}
\hline Variable & $\begin{array}{c}\text { Path } \\
\text { Coefficient }\end{array}$ & \multicolumn{1}{|c|}{ t- score } & Sig t & F - Score & R Square \\
\hline $\mathrm{X}$ & -0.024 & -0.487 & 0.627 & 1.071 & 0.379 \\
\hline $\mathrm{Y}$ & -0.124 & $-1,467$ & 0.145 & 1.071 & 0.379 \\
\hline
\end{tabular}

Source : Secondary data processed, 2020

To answer the research problem on whether the disclosure of corporate social responsibility affects investors' reactions, t-test statistic was tested. The results of the test show that if the indirect value $>$ direct value, $X$ indirectly influences $\mathrm{Z}$ through $\mathrm{Y}$ and vice versa. The direct effect of $\mathrm{X}$ on $\mathrm{Z}$ is (-0.042) and the indirect effect of $\mathrm{X}$ through $\mathrm{Y}$ on $\mathrm{Z}$ with $(-0.191 \mathrm{x}-0.124=0.02)$ is 0.02 . The results show that corporate social responsibility $(\mathrm{CSR})$ has an indirect value $(-0.02<-0.042)$. Variable $X$ indirectly affects $Z$ though. Therefore, $\mathrm{H}_{0}$ is rejected and $\mathrm{H}_{\mathrm{a}}$ is accepted.

It can be concluded from the results of the test that corporate social responsibility affects investor reactions. The results of this study are in line with the ones of (Nuzula \& Kato 2012; Wenbin Sun, Shanji Yao 2018), in which CSR was also found have an influence on investor reactions. The results of this study imply that the disclosure of corporate social responsibility in annual report reflects companies' current condition and future prospects. Information regarding CSR disclosure is useful for investors in making investment decisions.

\subsection{The Influence of Tax Aggressiveness on Investor Reaction}

To answer the research problem on whether tax aggressiveness has an effect on investor reaction, t-test statistic was performed. The results of the test showed $t$-value for variable $\mathrm{Y}$ was -1.467 with a significance value $=0.145$, the value of $\alpha=0.05$. The significance value $(0.145>0.05)$ shows that $H_{0}$ could not be rejected, while $H_{a}$ was rejected. The results imply that tax aggressiveness has no effect on investor reactions.

The results of this study are in line with the results of research by Frank, M., Lynch, L., Rego, S., (2009) showing that investors do not fully use accrual information and financial reports in making share purchase decisions and tax aggressiveness does not affect investor reaction.

\section{CONCLUSIONS AND SUGGESTIONS}

\subsection{Conclusions}

Based on the discussions, conclusions were drawn as follows.

1. Corporate social responsibility disclosure negatively affected tax aggressiveness.

2. Corporate social responsibility disclosure affected investor reaction.

3. Tax aggressiveness did not affect investor reaction 


\subsection{Suggestions}

1. There results of this study can be employed by companies in implementing their CSR and taxation decisions to prevent them from conducting tax aggressiveness which will affect investors in making investment decision. The government can also use the information obtained in this study in creating laws and regulations related to tax and CSR.

2. Both investors and company management are expected to make any decision carefully based on the tax regulations that apply. Instead of merely obeying the regulations, company management should perform more intensive monitoring to avoid making any tax avoidance.

3. The government is encouraged to strengthen the monitoring system toward companies that submit their tax reports to minimize the occurrence of tax avoidance.

\section{REFERENCES}

Chang, L. L., Hsiao, F. D., \& Tsai, Y. C. (2013). Earnings, institutional investors, tax avoidance, and firm value: Evidence from Taiwan. Journal of International Accounting, Auditing and Taxation, 22(2), 98-108. https://doi.org/10.1016/j.intaccaudtax.2013.07.001

Chen, X., Hu, N., Wang, X., \& Tang, X. (2014). Tax avoidance and firm value : evidence from China. Nankai Business Review International, 5(1), 25-42. https://doi.org/10.1108/NBRI-10-2013-0037

Chen, Y. C., Hung, M., \& Wang, Y. (2017). The effect of mandatory CSR disclosure on firm profitability and social externalities: Evidence from China. Journal of Accounting and Economics, 65(1), 169-190. https://doi.org/10.1016/j.jacceco.2017.11.009

Desai, M. A., \& Dharmapala, D. (2016). Corporate Tax Avoidance and Firm Value: Evidence from Brazil. The Review of Economics and Statistics, 91(August), 537-546. https://doi.org/10.2139/ssrn.2803993

Hlaing, K.P. (2012). Organizational Architecture of Multinationals and Tax Aggressiveness. University of Waterloo. Canada.

Huseynov, F., Klamm, B.K., 2012. Tax Avoidance, Tax Management and Corporate Social Responsibility. J. Corp. Financ. 18(4), 804-827

Jogiyanto. (2015). Metodologi Penelitian Bisnis: Salah Kaprah dan Pengalaman-pengalaman (kelima). Yogyakarta: BPFE-Yogyakarta.

Khaoula, A. (2013). Does Corporate Governance affect tax planning Evidence from American companies. International Journal of Advanced Research, 1(10), 864-868.

Laguir, I., Staglianò, R., \& Elbaz, J. (2015). Does corporate social responsibility affect corporate tax aggressiveness? Journal of Cleaner Production, 107, 662-675. https://doi.org/10.1016/j.jclepro.2015.05.059

Lanis, R., \& Richardson, G. (2011). The effect of board of director composition on corporate tax aggressiveness. Journal of Accounting and Public Policy, 30(1), 50-70. https://doi.org/10.1016/j.jaccpubpol.2010.09.003

Lanis, R., \& Richardson, G. (2012). J . Account . Public Policy Corporate social responsibility and tax aggressiveness: An empirical analysis. Journal of Accounting and Public Policy, 31(1), 86-108. https://doi.org/10.1016/j.jaccpubpol.2011.10.00

Lanis, R., \& Richardson, G. (2015). Is Corporate Social Responsibility Performance Associated with Tax Avoidance? Journal of Business Ethics, 127(2), 439-457. https://doi.org/10.1007/s10551-014-2052-8

Watson, L. Corporate social responsibility, tax avoidance, and earnings performance.J. Am. Tax. Assoc.2015,37, 1-21. [CrossRef]

Li, Y., Gong, M., Zhang, X., \& Koh, L. (2018). The impact of environmental, social, and governance disclosure on firm value: The role of CEO power. The British Accounting Review, 50(1), 60-75. https://doi.org/10.1016/j.bar.2017.09.007

Lin, K. Z., Cheng, S., \& Zhang, F. (2017). Corporate Social Responsibility, Institutional Environments, and Tax Avoidance Evidence from a Subnational Comparison in China. The International Journal of Accounting, 52(4), 1-30.

Laguir, I., Stagliano, R., Elbaz, J., (2015) Does corporate social responsibility affect corporate tax aggressiveness? Journal of Cleaner Production 107, 662-675. doi: 10.1016/j.jclepro.2015.05.059)

Minnick, K., Noga, T., 2010. Do corporate governance characteristics influence tax management? J. Corp. Financ. $16,703-718$.

Nela, S \& Aulia,B.B (2018) Pengaruh Cotporate Social Responsibility Terhadap Agresivitas Pajak dengan Profitabikitas sebagai Variabel Moderasi Pada Perusahaan LQ 45 di BEI

Nuzula, Nila F. dan Kato, Masanori. (2011). Do Japanese Capital Markets Respond to the Publication of Corporate Social Responsibility Reports?. Journal of Accounting, Finance and Economics Vol. 1. No. 1 : 4860.

Solimun, \& Rinaldo, A. (2009). Pemodelan Persamaan Struktural Pendekatan PLS dan SEM Aplikasi Software SmartPLS dan Amos. Malang: Laboratorium Statistika FMIPA Universitas Brawijaya Malang.

Watson, L. (2011). Corporate Social Responsibility and Tax Aggressiveness: An Examination of Unrecognized 
Tax Benefits. SSRN Electronic Journal.

Wenbin Sun, Shanji Yao, R. G. (2018). Reexamining CSR \& Shareholder Value, The Inverted-U-Shaped Relationship and the Moderation of Marketing Capability. Journal of Business Ethics, 1-18. Retrieved from https://doi.org/10.1007/s10551-018-3854-x

Zeng, Tao. (2012) Corporate Social Resposibility And Tax Aggresivnes. Social Science Research Network. 